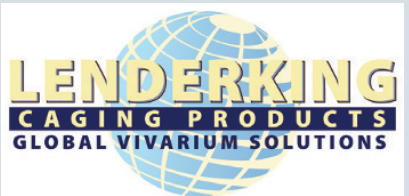

\title{
Hygieia Comfort Cages-better for the research mouse, better for your research dollars
}

\author{
Liz Kramer
}

Investigative research is the foundation of innovation that drives a first-world quality of life. Because we stand on the shoulders of scientific giants, we live longer, healthier and more productive lives than any humans in the history of civilization. The laboratory mouse is one tool that enables innovation to move forward, with 20-30 million mice used across the US each year ${ }^{1}$. Many variables contribute to the environment surrounding the laboratory mouse in an individually ventilated cage (IVC), such as the type of cage used, the composition and volume of bedding used, the number of air changes per hour $(\mathrm{ACH})$, the frequency of bedding changes, the frequency of cage changes and the temperature and relative humidity of air in the cage.

\section{Cages require proper upkeep}

The proper frequency at which cages should be changed is a subject of major debate, and members of the research community have strong opinions on the topic due to various biases. Traditionally, cage changes at a rate of once every $10-14 \mathrm{~d}$ are considered ideal for animal health and well-being ${ }^{2}$. Cage changes affect laboratory mice by disrupting scent cues, pheromoneladen breeding habits and nesting arrangements, generally stressing out the research mouse. The Guide for the Care and Use of Laboratory Animals states that "there is no absolute minimum frequency of bedding changes; the choice is a matter of professional judgment and consultation between the investigator and animal care personnel" and bedding should be changed so as to "keep pollutants, such as ammonia, at a concentration below levels irritating to mucous membranes" 3 . From the researcher standpoint, cage changes cost personnel time, consume bedding resources and require washing and sanitizing, which costs time, materials, water and energy. All of these demands cost research money. Additionally, cage changes increase personnel exposure to aeroallergens and ammonia when opening the cages. From the perspective of laboratory mice, research technicians and principal investigators, cage changes should be minimized to reduce the costs of research in general and to reduce stress on research subjects.

\section{Ammonia affects both mice and researchers}

Ammonia is produced when urine products come into contact with fecal bacteria, and as such, intracage ammonia concentrations follow a bacterial growth curve that is dependent on temperature and humidity. Ammonia levels correlate with adverse health effects

Lenderking Caging Products, Millersville, MD. Correspondence should be addressed to sales@lenderking.com.

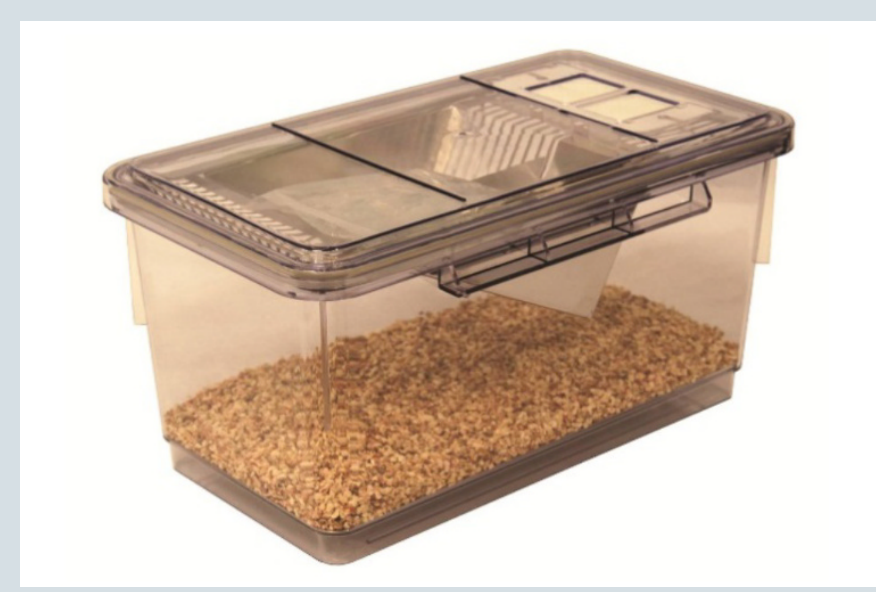

FIGURE 1 | Hygieia Comfort Cage extends the cage change frequency requirements past 21 days.

in mice such as corneal opacities, inflammation of nasal passages, thickened tracheal mucosa and olfactory epithelial necrosis in mice ${ }^{4,5}$. Pathogenic studies also show that high ammonia concentrations exacerbate the severity of respiratory infections such as rhinitis, otitis media, tracheitis and pneumonia ${ }^{6}$. These effects are exacerbated in static cages where rapid ammonia buildup causes demonstrable histopathological changes in the tracheal epithelium ${ }^{7}$. Overall animal welfare improves when bedding is kept dry, which results in lower levels of environmental ammonia.

Ammonia build-up is also a major concern from the standpoint of research technicians. The human safety threshold for prolonged exposure to ammonia is $100 \mathrm{ppm}$ over one hour, or $25 \mathrm{ppm}$ over eight hours. This makes the reduction of ammonia production a concern for the health and safety of research technicians as well as mice ${ }^{4,8}$. 


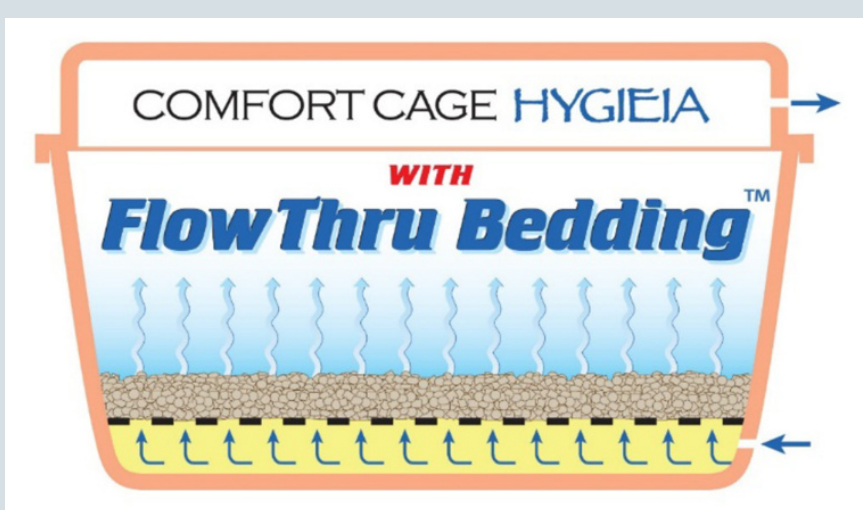

FIGURE 2 | The Flow Thru Bedding design allows fewer ACH to keep the bedding dry and reduce the atmospheric ammonia content as compared to standard IVC designs.

\section{Better cages, easier upkeep}

Lenderking Hygieia Comfort Cages with Flow Thru IVC design (Fig. 1) can safely house mice for intervals of $21 \mathrm{~d}$ between cage changes without causing any visible phenotypic/pathogenic effects (unpublished results). The decrease of cage change frequency with the associated labor, water, energy and transportation costs make the Lenderking Hygieia Comfort Cage the most cost-effective cage on the market. At a facility with 5,000 cages, changing Lenderking cages at a conservative rate of once every $21 \mathrm{~d}$, as compared to once every $10 \mathrm{~d}$ with standard IVC systems, leads to annual savings of more than $\$ 120,000$.

With air flowing through the bedding, the bedding is kept drier, which reduces the ammonia content inside the cage. This makes the cage environment healthier for both standard and breeding laboratory mouse models. The patented design (Fig. 2) requires fewer $\mathrm{ACH}$ than conventional IVC systems, which decreases energy costs and is less disruptive to the scent and pheromone cues that mice accumulate in their cages over time. With drier bedding, variables of temperature and relative humidity are also easier to control.

\section{An ideal system from any perspective}

From the standpoint of principal investigators, Hygieia Comfort Cages will save hundreds of thousands of dollars per year throughout the lifetime of the equipment by reducing labor and resources. For technicians, the Hygieia Comfort Cage reduces their exposure to ammonia and other aerosolized particles, and for laboratory mice, Hygieia decreases stress, increases pheromone persistence and does not require disruption of nesting activities as frequently as other cages. To get better results from your test subjects and keep more of your research dollars in variables, not infrastructure, the Hygieia Comfort Cage is the right choice!

\section{Company profile}

Founded in 1867, Lenderking is America's oldest caging company. We are committed to providing you with the best solutions and value when housing research animals. We use only American made materials and labor. Our All-American ideas have been leading the industry since the last century.

1. Anft, M. Of mice and medicine. Johns Hopkins Magazine. September 2008.

2. Reeb-Whitaker, C.K. et al. The impact of reduced frequency of cage changes on the health of mice housed in ventilated cages. Lab. Anim. 35, 58-73 (2001).

3. Institute for Laboratory Animal Research. Guide for the Care and Use of Laboratory Animals $8^{\text {th }}$ edn. (National Academies Press, Washington, DC, 2011).

4. Milite, G. A Comparative study on ammonia level in IVC sealsafe cages with three different bedding materials. Effects on water and feed intake, body growth and pre-weaning mortality over a fourteen days period. Techniplast Resource Library GM/26 Report (2014).

5. Rosenbaum, M.D., VandeWoude, S. \& Johnson, T.E. Effect of cage-change frequency and bedding volume on mice and their microenvironment. J. Am. Assoc. Lab. Anim. 48, 763-773 (2009).

6. Broderson, J.R., Lindsey, J.R. \& Crawford, J.E. The role of environmental ammonia in respiratory mycoplasmosis of rats. Am. J. Pathol. 85, 115-130 (1976).

7. Gamble, M.R. \& Clough, G. Ammonia build-up in animal boxes and its effect on rat tracheal epithelium. Lab. Anim. 10, 93-104(1976).

8. Clough, G., Wallace, J., Gamble, M.R., Merryweather, E.R. \& Bailey, E. A positive, individually ventilated caging system: a local barrier system to protect both animals and personnel. Lab. Anim. 29, 139-151 (1995). 